\title{
Pressure injury associated with mechanical restraint: a cross-sectional study
}

Lesão por pressão associada à contenção mecânica: estudo transversal Lesión por presión asociada a la contención mecánica: estudio transveral

Livia Maria da Silva Souza ${ }^{1}$, Rosimere Ferreira Santana, ,*, Marcia Verissimo de Souza ${ }^{1}$, Simone Martins Rembold ${ }^{2}$, Arianna Kassiadou Menezes ${ }^{3}$

ORCID IDS

Souza LMS (D) https://orcid.org/0000-0002-5225-2045

Santana RF (D) https://orcid.org/0000-0002-4593-3715

Souza MV (D) https://orcid.org/0000-0001-9627-9824

Rembold SM (D) https://orcid.org/0000-0003-1424-747X

Menezes AK (iD https://orcid.org/0000-0002-9159-3002
HOW TO CITE

Souza LMS, Santana RF, Souza MV, Rembold SM, Menezes AK. Pressure injury associated with mechanical restraint: a cross-sectional study. ESTIMA, Braz. J. Enterostomal Ther., 17: e0919. https://doi. org/10.30886/estima.v17.703_IN

\begin{abstract}
Objective: To verify the association of the practice of mechanical restraint with pressure injury (PI) in hospitalized patients. Method: A cross-sectional study of 111 patients from medical, surgical and intensive care units at a public hospital in the state of Rio de Janeiro, Brazil. To analyze the association between variables, the [odds ratio (OR)] was adopted. Results: It were found 57 patients in mechanical restraint (51.4\%). In the group of patients contained, the occurrence of PI was estimated in $43.9 \%$ and in the group of patients not contained in 5.6\%. The chance of the contained patient to present PI was 13 times higher than in patients not contained. The location of the injury was more frequently in the sacral region, classified as stage $2(21.1 \%)$ and stage 3 (12.3\%), followed by trochanter (15.8\%) and calcaneus (10.5\%). Conclusion: It is recommended the adoption of nursing practices of suppression or reduction of the time in the use of mechanical restraint, adopting educational measures and prevention of PI.
\end{abstract}

DESCRIPTORS: Stomatherapy; Pressure ulcer; Physical restraint.

\footnotetext{
1. Universidade Federal Fluminense - Escola de Enfermagem Aurora de Afonso Costa - Niterói/RJ - Brazil.

2.Universidade Federal Fluminense - Escola de Enfermagem Aurora de Afonso Costa - Departamento de Enfermagem Médico-

Cirúrgica - Niterói/RJ - Brazil.

3.Universidade Federal Fluminense - Escola de Enfermagem Aurora de Afonso Costa - Programa de Pós-Graduação em Ciências do Cuidado em Saúde - Niterói/RJ - Brazil.

*Correspondence author: rosifesa@gmail.com

Received: 25 Jan 2019 | Accepted: 10 May 2019
} 


\section{RESUMO}

Objetivo: Verificar associação da prática de contenção mecânica com lesão por pressão (LP) em pacientes hospitalizados. Método: Estudo transversal realizado com 111 pacientes de unidades de clínica médica, cirúrgica e de terapia intensiva em um hospital público do estado do Rio de Janeiro, Brasil. Para analisar a associação entre as variáveis, adotou-se a razão de chances [odds ratio (OR)]. Resultados: Encontraram-se 57 pacientes em contenção mecânica (51,4\%). No grupo de pacientes contidos, a ocorrência de LP foi estimada em 43,9\% e, no grupo de não contidos, em 5,6\%. A chance de o paciente contido apresentar LP foi 13 vezes maior do que em pacientes não contidos. A localização da lesão foi mais frequentemente na região sacra, classificada em estágio 2 (21,1\%) e estágio 3 (12,3\%), seguida de trocânter (15,8\%) e calcâneo (10,5\%). Conclusão: Recomenda-se a adoção de práticas de enfermagem de supressão ou redução do tempo no uso da contenção mecânica, adotando medidas educativas e de prevenção da LP.

DESCRITORES: Estomaterapia; Úlcera por pressão; Restrição física.

\section{RESUMEN}

Objetivo: Verificar la asociación de la práctica de contención mecánica con lesión por presión (LP) en pacientes hospitalizados. Método: Estudio transversal realizado con 111 pacientes de unidades de clínica médica, quirúrgica y de terapia intensiva en un hospital público del estado de Río de Janeiro, Brasil. Para analizar la asociación entre las variables, se adoptó la razón de posibilidades [odds ratio (OR)]. Resultados: Se encontraron 57 pacientes en contención mecánica (51,4\%). En el grupo de pacientes contenidos, la ocurrencia de LP fue estimada en el 43,9\% y, en el grupo de no contenidos, en el 5,6\%. La posibilidad de que el paciente contenía presentar LP fue 13 veces mayor que en pacientes no contenidos. La localización de la lesión fue más frecuentemente en la región sacra, clasificada en etapa $2(21,1 \%)$ y etapa $3(12,3 \%)$, seguida de trocánter (15,8\%) y calcáneo (10,5\%). Conclusión: Se recomienda la adopción de prácticas de enfermería de supresión o reducción del tiempo en el uso de la contención mecánica, adoptando medidas educativas y de prevención de la LP.

DESCRIPTORES: Estomaterapia; Úlcera por presíon; Restricción física.

\section{INTRODUCTION}

Mechanical restraint is often used in hospitals to prevent falls, to control patients with psychomotor agitation, and to avoid discontinuation of treatment. However, its use is questioned because it restricts the autonomy and freedom of the patient, besides it being related to potential adverse events ${ }^{1,2}$.

It is considered mechanical restraint the use of devices that restrict the individual's movement to a position of its choice and/or access to its own body 5 . In the hospital environment, the devices most used for restraint are bands applied to the pulses, elbows, ankles, and abdomen ${ }^{1,3}$. The lateral bed rails are considered, in some studies, safety equipment in the prevention of falls ${ }^{2}$.

The inappropriate use of mechanical restraint, widely studied in long-term institutions for the elderly (LTIFEs), can cause damage that varies in intensity. It is cited from impairment of cognitive abilities, muscular atrophy or worsening of existing atrophy, pressure injury (PI), urinary and fecal incontinence, contractures, injuries, pneumonia, deep vein thrombosis, until fatal damage due to asphyxia ${ }^{2,4,5,22}$.
The elderly population has been more exposed to restraint in the hospital environment, having as contributors the difficulty of mobility, the risk of fall, dependence, and polypharmacy ${ }^{3}$. Information on adverse events associated with mechanical restraint in general hospitals is still limited. Studies conducted in hospitals report PI and catheterrelated urinary tract infection as events from the use of restraint ${ }^{3,6}$. In the elderly, complications result in increased morbidity, mortality and costs ${ }^{6}$.

The study conducted at an Israel hospital with 2.163 patients admitted to medical and surgical clinics and intensive care units reported the presence of PI as a predictor for restraint use. In this study, the lateral bed grids were not considered restraint devices ${ }^{3}$.

PIs constitute a complex, multifactorial problem, resulting in high costs at the individual, family, and socioeconomic levels ${ }^{6,8,11}$. The appearance of PI causes several physical and emotional disorders to the patient, such as discomfort, pain, stress, increased risk of complications, prolonged hospitalization, influence on morbidity and mortality ${ }^{8,12}$. 
PI is considered a common problem, especially in elderly and immobilized people, and occurs in approximately $10 \%$ of hospitalized patients ${ }^{13,14}$. It is evidenced the increase in its prevalence in the last years due to the greater life expectancy ${ }^{8}$. The prevalence of PIs increases with age, occurring in 50 to $70 \%$ of patients older than 75 years $^{9}$. Although frequent, the occurrence of this injury is presumably avoidable in at least $95 \%$ of patients $^{10,15}$. In this sense, Ordinance no 529 of 2013 of the Ministry of Health instituted the National Program of Patient Safety, aiming to reduce, to an acceptable minimum, the risk of damage associated with health care. The program explains that PI is considered an adverse event since it results in damage to the patient, and its occurrence is monthly compulsory notification ${ }^{23}$.

Intrinsic and extrinsic factors can affect skin and soft tissue conditions, reducing resistance to pressure and shearing, among which advanced age, loss of sensitivity, altered level of consciousness, dependence on self-care, prolonged hospitalization, microclimate, reduced mobility or immobility, diabetes, hypertension, low diastolic blood pressure, urinary or anal incontinence, muscle spasms, deficient nutritional status, anemia, extremes of body mass index, immunological deficiency and smoking ${ }^{8,11}$. The use of medications may also contribute to this type of injury, such as corticosteroids ${ }^{8}$, antibiotics, antiinflammatories ${ }^{13}$ and anticoagulants ${ }^{14}$. Other factors that may be inappropriate in the practice of care deserve to be highlighted, such as the use of medical devices, repositioning and/or support surface, hygiene, and the necessity for dry skin protection, use of moisturizer ${ }^{16}$, use of diaper and also mechanical restraint ${ }^{11}$.

Therefore, this study aims to verify the association of the practice of mechanical restraint with PI in hospitalized patients.

\section{METHODS}

An observational and cross-sectional study realized in a public hospital located in a municipality of the lowland coastal mesoregion, in the state of Rio de Janeiro. The hospital realizes outpatient and hospital care of medium and high complexity and it has 70 beds.

According to data from the Department of Informatics of the National Health System (Datasus), the hospital registered 489 hospitalizations in the adult hospitalization sectors from January to August 2016. Thus, the population of interest was 489 patients. To obtain the results of interest, due to the impossibility of interviewing the entire population, a sample of this universe was withdrawn. The minimum sample size for this study was 106 patients contained and not contained.

Inclusion criteria were adults and elderly hospitalized in the medical clinic, surgical clinic, and intensive care unit; as an exclusion criterion, it was not included to include the emergency due to the shorter patient stay in this sector.

Data were collected from June 28 to November 28, 2017, with a total of 111 participants. Visits occurred three times a week, on alternating days and times, and were performed by a single researcher, in the morning and afternoon turns. All scenarios were visited on collection days and patients older than 18 years were identified. After obtaining informed consent, a clinical approach was performed to evaluate the patients and to fill out the observation instrument for the use of mechanical restraint.

The instrument used was developed by Evans et al. to record the use of mechanical restraint in the elderly living in LTIFEs in the United States ${ }^{17}$. For the use of this instrument, authorization was requested. After the consent, adjustments were made for applicability in the hospital scenario, ie, the words associated with the LTIFE scenario by Hospital were changed.

With this instrument, it was possible to obtain identification information for each participant, if it was contained and what type of restraint used, date, gender, age, and hospitalization unit. Data were then collected from the variables: date of admission, medical diagnosis, reasons and time of use of mechanical restraint, use of invasive devices, presence, and staging of PI. PIs were identified during the clinical evaluation. The team and/ or companions were questioned about the presence of injuries and the researcher evaluated the type, site, and staging. To complement the direct observation, there was a consultation to the patients' medical records.

From the data collected, a database was built in Microsoft Excel 2010 for analysis by the Statistical Package for the Social Science - SPSS version 22.0. For the characterization of the sample in the descriptive analysis of the behavior of the variables, the data were synthesized 
through the calculation of descriptive statistics, graphs, simple frequency distributions, and cross tables.

In an inferential analysis, the proportions of interest were also estimated by confidence interval (CI) for proportions. The significance of the association between two qualitative variables was investigated by the chi-square test, and when this was inconclusive, it was appropriated by Fisher's exact test. The risk ratio was the [odds ratio (OR)], which assessed the relationship between the chance of a contained individual presenting PI compared to that of the uncontained individual, with a CI greater than 1 .

The study was approved by the Research Ethics Committee of the Antonio Pedro University Hospital of Fluminense Federal University under opinion 2.172.275.

\section{RESULTS}

Regarding gender, the predominance of women patients (61.1\%) was predominant in the non-contained group and, among the patients, men predominated (64.9\%). As to the age distribution, a greater concentration of patients under 58 years old (44.4\%) was observed in the group of noncontained patients, while the majority of patients were over 68 years old $(49.20 \%)$.

Of the 111 patients observed, 57 were found in mechanical restraint, with an estimated prevalence of $51.4 \%$. The most prevalent type of mechanical restraint was the use of lateral bed grids (100\%); in $70.2 \%$ of the patients, only the grid was used and $29.8 \%$ of the patients were also with the pulses contained. The most common reason for the contention was the risk of falls (100\%) followed by the use of invasive devices (57.9\%).

The overall occurrence of PI was $25.2 \%$ (28 patients). In the group of patients not contained, the occurrence of PI was 5.6\% (three patients), and in the group of patients contained the occurrence was $43.9 \%$ (25 patients). There was an association between the use of mechanical restraint and the presence of PI. The OR of a contained patient presented PI was 13.3 times greater than that of a patient not contained, with significant CI (3.7-47.6). Fig. 1 shows the occurrence of PI in the two groups and in the overall sample.

PIs occurred mainly in the sacral region and were characterized in stage 2 . The distribution by location and stage of the injury can be seen in Figs. 2 and 3, respectively.

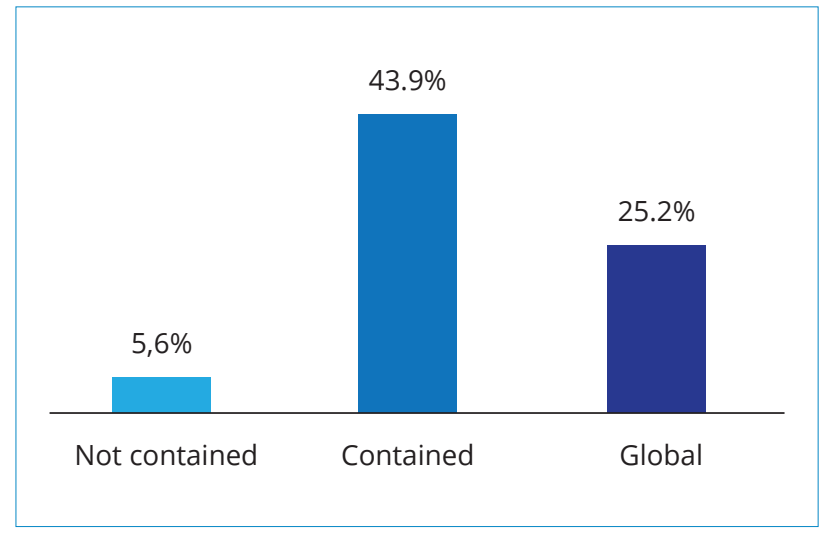

Figure 1. Occurrence of pressure injuries in the study sample.

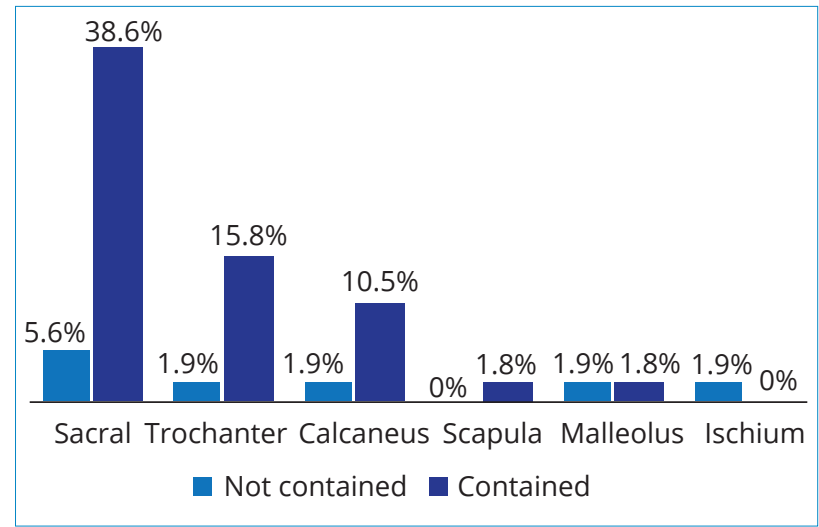

Figure 2. Occurrence of pressure injury by anatomical location of the injury.

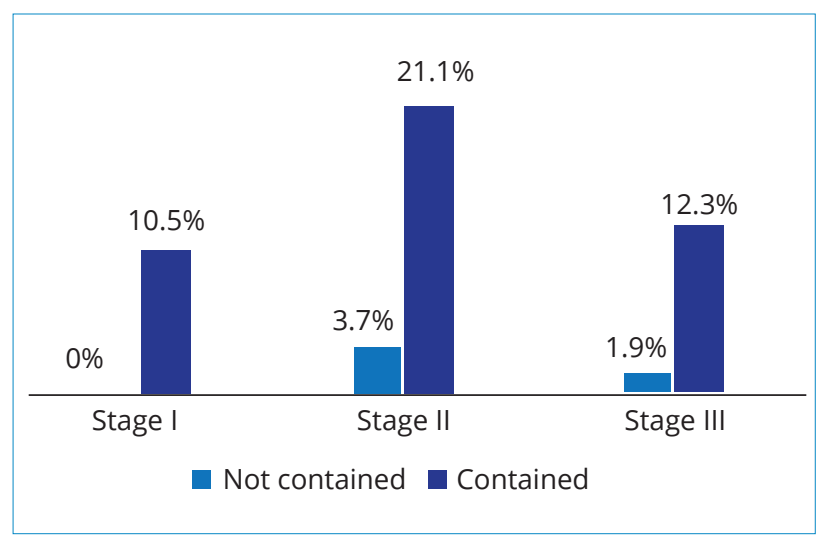

Figure 3. Occurrence of pressure injury per stage of the injury.

\section{DISCUSSION}

The main data of this study was the association between the occurrence of PI and the practice of mechanical restraint. The importance of this data is demonstrated with an estimated $43.9 \%$ occurrence of PI in patients, totaling 25 patients, while in the noncontained group, the occurrence was only $5.6 \%$, that is, three patients. It was verified that the chances of 
contained patients presenting PI were 13 times higher in patients with mechanical restraint than in those not contained. Other studies also revealed a correlation between the use of mechanical restraint and the outcome of PI but did not use measures of comparison in relation to patients not contained. ${ }^{3,6}$

The incidence of PI is considered an important indicator of nursing care quality and should be analyzed in terms of its distribution, which patients are most vulnerable and where they are most frequent ${ }^{8}$. Risk assessment instruments for skin integrity were validated, such as the Norton, Gosnell, Waterlow and Braden scales, in order to guide measures for the prevention of $\mathrm{PI}^{16}$. However, in these assessment instruments used by the nursing team, mechanical restraint is not considered a predisposing factor. It is estimated that preventive measures make it possible to reduce the incidence of PI by $50 \%$, and among these, the reduction of the use of mechanical restraint ${ }^{18}$.

With a view to prevention and systematic control of damages that may be caused to clients during nursing care, COFEN ( Nursing Federal Council) Resolution nº. 427 of 2012 recommends the use of mechanical restraint only when it is the only means available to prevent immediate or imminent damage to the patient or to the others, preferably from protocols of the institution that determine its indication, except emergency and emergency situations ${ }^{19}$.

Mechanical restraint should be applied under the direct supervision of the nurse and, during its use, the nursing team should inspect the skin and circulation in the patient's premises and limbs regularly, as well as the clinical monitoring of the level of consciousness, of data not exceeding one hour. Patients under sedation, sleepy or with some clinical problem, as well as elderly, children and adolescents, should be monitored with greater accuracy. The time of use of the restraints should be as strict as necessary, and the indications for use and the duration of its use, the occurrence of adverse events, as well as the details regarding clinical monitoring ${ }^{19}$.

Therefore, from the research data, it is suggested that people with mechanical restraint have a greater chance of developing pressure injuries, and preventive measures should be instituted to maintain the integrity of the skin in these patients, and rigorous monitoring and evaluation of the indices of PI, considered important indicators of the quality of nursing care $^{8}$.
Regarding the topography, the most affected region was the sacral, followed by the trochanter and the calcaneus. The data corroborate the results of other studies in which injuries were predominant in the same topography because it is supporting regions when the patient is in the supine or lateral position ${ }^{8-10}$.

The patients presented a higher frequency of injuries in stages $2(21.1 \%)$ and $3(12.3 \%)$. Although it is not possible to establish a causal relationship since PIs generally result from several associated factors, patients with mechanical restraint often have impaired mobility, and it is observed that this restraint further reduces movement $t^{6,22}$ and its use be discontinued as soon as possible. The treatment of injuries in these stages implies the use of a greater quantity of products, increasing the costs of the assistance ${ }^{24}$.

The use of restraint prevailed in men, is the same found in other studies ${ }^{3,21}$. As for age, there was a greater proportion of elderly people contained. It is observed that this segment is more exposed to mechanical restraint and, associated with the restriction of movement by its use and other factors related to aging, such as increased skin fragility ${ }^{7}$, urinary, and fecal incontinence ${ }^{8,22}$, increase the chances of developing PIs during hospitalization.

In this study, the reason cited by the team for the use of restraint was the risk of falling followed by the use of invasive devices. A case-control study that related the risk of falling with patient profile and medication use identified that hospital bed fall has multifactorial etiology, such as gait problems or lack of strength in the lower limbs, frequency of physiological eliminations, urinary incontinence, and confusion, as well as the use of antipsychotic or sedative medication ${ }^{20}$.

The study presented as limitations the fact that the research was performed in a single hospital, in the morning and afternoon turn and by a single researcher. This research, because it was transversal, did not allow to specify the moment of the occurrence of PI in the use of contention. There is a necessity to explore other factors that contribute to tissue injury and the severity of the patients that may be confusing. It was also not possible to affirm that there is a causal relationship between the results found and the use of mechanical restraint, but it is suggested to perform a longitudinal design, despite the limiting ethical issues, since to the extent that there are patients contained in the long term 
and evolving with PI, the search should be stopped. However, it is possible to identify an association between the researched factors that deserve other studies, as well as the wide dissemination on the subject.

\section{CONCLUSION}

It is concluded that patients in mechanical restraint are more likely to develop PI, especially those elderly who are more predisposed due to the cognitive deficit and motor difficulty, reasons that converge to the appearance of PI, formulating a vicious circle that causes damages to patients and compromises the quality of nursing care.

In the institutional managerial aspect, organizational and environmental strategies can lead to a reduction of the use of restraint and consequently of fall rates. Approaches are recommended for cognitive and motor improvement of the patient, such as mobilization and repositioning, hygiene and daily skin care and injuries. However, it is fundamental to develop educational actions for PI prevention and compliance with standardized procedures for the use of mechanical restraint.

\section{AUTHORS' CONTRIBUTION}

Conceptualization, Souza LMS, Santana RF and Menezes AK; Methodology, Santana RF and Rembold SM; Investigation, Souza LMS; Writing - First version, Souza LMS and Santana RF; Writing - Review \& Edition, Santana RF, Souza MV de, and Rembold SM; Acquisition of Financing, Santana RF and Souza LMS; Resources, Santana RF and Souza LMS; Supervision, Santana RF.

\section{FUNDING}

Fundação Carlos Chagas Filho de Amparo à Pesquisa do Estado do Rio de Janeiro [https://doi. org/10.12039/501100004586]

Grant No.: 200.990/2017.

\section{REFERENCES}

1. Krüger C, Mayer $H$, Haastert B, Meyer G. Use of physical restraints in acute hospitals in Germany: a multi-centre cross-sectional study. Int J Nurs Stud. 2013;50(12):15991606. https://doi.org/10.1016/j.jinurstu.2013.05.005

2. Estêvez-Guerra GJ, Fariña-López E, Núñez-González E, Gandoy-Crego M, Calvo-Francés F, Capezuti EA. The use of physical restraints in long-term care in Spain: a multi center cross-sectional study. BMC Geriatrics. 2017;17(1):29. https://doi.org/10.1186/s12877-017-0421-8

3. Raguan B, Wolfovitz E, Gil E. Use of physical restraints in a general hospital: a cross-sectional observational study. Isr Med Assoc J. 2015;17(10):633-8.

4. Steinert $T$, Lepping $P$, Bernhardsgrütter R, Conca A, Hatling T, Janssen $\mathrm{W}$, et al. Incidence of seclusion and restraint in psychiatric hospitals: a literature review and survey of international trends. Soc Psychiatry Psychiatr Epidemiol. 2010;45(9):889-97. https:// doi.org/10.1007/s00127-009-0132-3

5. Berzlanovich AM, Shöpfer J, Keil W. Deaths due to physical restraint. Deutsch Äztebl Int. 2012;109(3):27-32. https://doi. org/10.3238/arztebl.2012.0027

6. Bleijlevens MH, Wagner LM, Capezuti E, Hamers JP. Physical rRestraints: consensus of a research definition using a modified Delphi technique. J Am Geriatr Soc. 2016;64(11):2307-10. https://doi.org/10.1111/jgs.14435

7. Oearsakul B, Sirapo-Ngam Y, Strumpf NE, Malathum P. Physical restraint use among hospitalized elderly thais. Pacific Rim Int J Nurs Res. 2011;15(2):125-36.

8. Moraes JT, Borges EL, Lisboa CR, Cordeiro DCO, Rosa EG, Rocha NA. Conceito e classificação de lesão por pressão: atualização do National Pressure Ulcer Advisory Panel. Enferm Cent O Min. 2016;6(2):2292-2306. https://doi. org/10.19175/recom.v6i2.1423

9. Sanders LSDC, Pinto FJM. Ocorrência de úlcera por pressão em pacientes internados em um hospital público de Fortaleza-CE. Reme - Rev Min Enferm. 2012;16(2):166-70.

10. Borghardt AT, Prado TND, Bicudo SDS, Castro DSD, Bringuente MEO. Pressure ulcers in critically ill patients: incidence and associated factors. Rev Bras Enferm. 2016;69(3):460-7. https://doi.org/10.1590/0034$7167.2016690307 i$

11. He M, Tang A, Ge X, Zheng J. Pressure ulcers in the intensive care unit: an analysis of skin barrier risk factors. Adv Skin Wound Care. 2016;29(11):493-8. https://doi.org/10.1097/01. ASW.0000494779.66288.c9 
12. Arenas EB, Castañeda MDCP, Jiménez GP, Jiménez PH, Rodríguez JAR, Zárate MPP. Prevalencia de úlceras por presión en un hospital de tercer nivel, en México DF. Gerokomos. 2016;27(4):176-81.

13. Ricci JA, Bayer LR, Orgill DP. Evidence-based: the evaluation and treatment of pressure injuries. Plast Reconstr Surg. 2017;139(1):275e-86e. https://doi.org/10.1097/ PRS.0000000000002850

14. Greenhalgh DG. Management of the skin and soft tissue in the geriatric surgical patient. Surg Clin North Am.2015;95(1):10314. https://doi.org/10.1016/j.suc.2014.09.008

15. Belén FT. Formación y prevención en úlceras por presión: prevalencia en el Hospital General de Elche. Gerokomos. 2016;27(1):33-7.

16. Wechi JS, Amante LN, Salum NC, Matos E, Martins T. Escala de Braden: instrumento norteador para prevenção de úlcera por pressão. ESTIMA, Braz J Enterostomal Ther. 2017;15(3):14551. https://doi.org/10.5327/Z1806-3144201700030005

17. Evans LK, Strumpf NE, Allen-Taylor SL, Capezuti E, Maislin $\mathrm{G}$, Jacobsen B. A clinical trial to reduce restraints in nursing homes. J Am Geriatr Soc. 1997;45(6):675-81. https://doi. org/10.1111/j.1532-5415.1997.tb01469.x

18. Araújo TM, Araújo MFM, Caetano JÁ. O uso da escala de Braden e fotografias na avaliação do risco para úlceras por pressão. Rev Esc Enferm USP. 2012;46(4):858-64. https:// doi.org/10.1590/S0080-62342012000400011.
19. Conselho Federal de Enfermagem. Resolução COFEN Nº 427 from 07 May 2012 [Internet]. Brasília, DF; 2012 [cited 14 Jan 2019]. Available at: http://www.cofen.gov.br/resoluocofen-n-4272012_9146.html

20. Krauss MJ, Evanoff B, Hitcho E, Ngugi KE, Dunagan WC, Fischer I, et al. A case-control study of patient, medication, and care-related risk factors for inpatient falls. J Gen Intern Med. 2005;20(2):116-22. https://doi.org/10.1111/j.15251497.2005.40171.x

21. Snaches B, Contrin LM, Beccaria LM, Frutuoso IS, Silveira AMR, Werneck AL. Adesão da enfermagem ao protocolo de lesão por pressão em unidade de terapia intensiva. Arch Health Sci. 2018;25(3):27-31. https://doi.org/10.17696/23183691.25.3.2018.1058

22. Hofmann H, Hahn S. Characteristics of nursing home residents and physical restraint: a systematic literature review. J Clin Nurs. 2013;23:3012-24. https://doi. org/10.1111/jocn.12384

23. Ministério da Saúde (BR). Portaria No 529 de 01 de abril de 2013 [Internet]. Brasília, DF; 2013. [citado 14 Jan 2019]. Disponível em: http://bvsms.saude.gov.br/bvs/saudelegis/ gm/2013/prt0529_01_04_2013.html

24. Silva DRA, Bezerra SMG, Costa JP, Luz MHBA, Lopes VCA, Nogueira LT. Curativos de lesões por pressão em pacientes críticos: análise de custos. Rev Esc Enferm USP. 2019;51:e03231. http://dx.doi.org/10.1590/s1980$220 \times 2016014803231$ 